\title{
correspondence
}

\section{New president of} Soviet Academy

SIR,--In your recent article "Appointment to Soviet Academy threatens autonomy" (December 4, page 377), your correspondent's interpretation of the changes in the Academy leadership was superficial and prejudiced. The conclusion that the replacement of Academician V. A. Kotel'nikov by Academician A. P. Alexandrov indicates "a greater degrce of Government supervision of the Academy's work in future" was made, first, because Alexandrov was introduced at the Academy meeting by Politburo member M. A. Suslov and not by somebody from the Academy's own ranks, and, second, because Alexandrov himself is a member of the Central Party Committee Plenum.

Both aspects are irrelevant in any assessment of the Academy's future. The replacement had to be made by a high Party or Government official because the Academy is not and never has been independent; it is a State scientific establishment.

With the position of the chairman of the "Ideological Commission"which includes the Party's department on science and education-vacant more than a year already, M. A. Suslov (as top Party ideologist) is now the highest official responsible for science and education. There is also nothing sinister in the fact that Alexandrov is a member of the Central Party Committee. The most liberal Russian poet, writer and editor Alexander Tvardovsky was also a member of the Central Party Committee.

I consider that the election of Alexandrov now is a concession from the Government, a move to meet the demand of the Academy for a more popular and prominent figure. If this is so, the new election is a liberal decision, and does not reflect an increase of political pressure. Moreover, regarding Alexandrov himself, it should be noted:

- When, during Khrushchev's time, classical genetics was still forbidden and Lysenko reigned supreme, the only place where large-scale, serious genetic research was possible was the big biological division of the Kurchatov Institute of Atomic Energy headed by Alcxandrov-a division created specifically for confrontation with Lysenko pseudogenetics.

- When in 1966 Alexander Solzhenit- syn decided to give public readings from his banned novels, the only place where he was ablc to do this was the Kurchatov Institute. The hundreds of scientists there warmly welcomed the writer, and Alexandrov was reprimanded for taking this liberty.

- When in 1970 I was put by force into a mental hospital for political reasons, academicians who acted on my behalf, strongly and voluntarily, included Alexandrov. Indeed, he was the most influential among them, and the only one who did not know me personally, yet he spoke strongly in support of my immediate release.

- Alexandrov's predecessors, Kotel'nikov and M. V. Keldysh, signed a letter to Pravda on August 29, 1973, against A. Sakharov. Alexandrov did not.

The Soviet Academy, being a state body, has never really been autonomous. But it has moral authority and political influence which derives mostly from the personal prestige of academicians and their scientific stature. It also stems from the courage of some of the Academy's best people in their struggle for scientific integrity and scientific and human rights. This struggle has not always been successful, but there have been several cases in recent years when the majority of the Academy has strongly opposed Government pressure on certain issues.

Your correspondent was also wrong to predict a short term for Alexandrov merely because of his age. The position of president is not tenured for life; it is subiect to re-election every five years. The only president who was not able to complete this minimum term was the young and bright Sergei Vavilov, who died from a heart attack in 1951 .

\section{National Institute \\ for Medical Research, London, UK}

Yours faithfully, Zhores A. Medvedev

\section{Multiplying ventures}

SIR,---During the past fortnight I have received three communications on the formation of new groups. The first of these is from the Society of Experimental Biology; it refers to the formation of a neurobiology group. The second one comes from the secretariat of a newly formed European Neuroscience Association. The third one is a communication concern- ing the first meeting of a newly formed European Society of Neurochemistry.

I am already a member of the International Brain Research Organisation (IBRO) and I believe I am also a member of the International Society for Neurochemistry. I also frequently attend meetings of the Neurochemistry Group which meets under the auspices of the Biochemical Society.

Faced with this plethora of new ventures one is tempted to ask the organisers: "Is your venture really necessary?" It seems to me as if in this field there is a development of much overlap. Is there no roof organisation that could be consulted when such new societies are formed? The European Neuroscientists' missive contains the threat that "a fee structure should be set up by the first Council for individual membership". The European Neurochemists require a registration fee of not more than $£ 15$ for participant members of their first meeting.

For one whose interests happen to bridge the areas of several or all of these bodies considerable monetary expenditure seems to be involved. Surely this multiplication of organisational effort is not in the spirit of the times.

$$
\begin{aligned}
& \text { Yours faithfully, } \\
& \text { H. Bi.Aschxo } \\
& \text { University Department of } \\
& \text { Pharmacology, } \\
& \text { Oxford, UK }
\end{aligned}
$$

\section{Journal guidelines}

SIR,-Why does Professor Ziman think it a populist folly to disclose the names of referees to authors? In the Journal of Aerosol Science, 1 (1), 1970, I wrote "A feature of the new journal is that no cloak of mystery will shroud those who accept, reject or accept subject to modification the papers which are submitted to it. There are three reasons for this unorthodox exposure of the referee. First, the authoritarian age is over, second, the standard of critique will be raised and lastly, it is hoped, encouragement and benefit will result to authors."

Six volumes of editorial experience confirm this statement. What has Professor Ziman to offer in support of his assertion?

$$
\begin{aligned}
& \text { Yours faithfully, } \\
& \text { C. N. Davies }
\end{aligned}
$$

Department of Chemistry,

University of Essex, UK 